\title{
COMPUTED TOMOGRAPHIC EVALUATION OF OPTIC NERVE PATTERNS IN INDIAN POPULATION
}

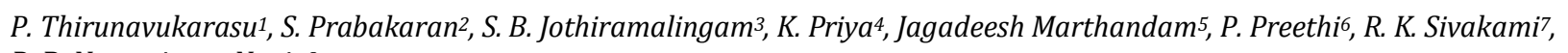

R. B. Namasivaya Navin ${ }^{8}$

${ }^{1}$ Associate Professor, Department of ENT, Chettinad Hospital and Research Institute.

2Post Graduate, Department of ENT, Chettinad Hospital and Research Institute.

${ }^{3}$ Professor and HOD, Department of ENT, Chettinad Hospital and Research Institute.

${ }^{4}$ Assistant Professor, Department of ENT, Chettinad Hospital and Research Institute.

${ }^{5}$ Senior Resident, Department of ENT, Chettinad Hospital and Research Institute.

${ }^{6}$ Senior Resident, Department of ENT, Chettinad Hospital and Research Institute.

${ }^{7}$ Post Graduate, Department of ENT, Chettinad Hospital and Research Institute.

${ }^{8}$ Post Graduate, Department of ENT, Chettinad Hospital and Research Institute.

\begin{tabular}{l} 
ABSTRACT \\
\hline OBJECTIVE
\end{tabular}

To determine the incidence of optic nerve patterns in sphenoid sinus in the Indian population.

\section{METHODS}

Computed tomographic scans of paranasal scans were reviewed. Optic nerve configurations were assessed using DeLano's classification.

\section{RESULTS}

202 optic nerves in 101 patients were studied. Type I configuration was commonest with 55.45\% followed by Type II (23.27\%), Type IV (11.88\%) and Type III (9.40\%). Onodi cells were significantly found to be left sided (61.9\%) in our study.

\section{CONCLUSION}

Our study corresponds to the studies done in western literature. We differ in having no optic nerve dehiscence and the Onodi cell being predominantly left sided.

\section{KEYWORDS}

Optic Nerve, Delano Classification, Endoscopic Sinus Surgery, Onodi Cell.

HOW TO CITE THIS ARTICLE: Thirunavukarasu P, Prabakaran S, Jothiramalingam SB, et al. Computed tomographic evaluation of optic nerve patterns in Indian population. J. Evolution Med. Dent. Sci. 2016;5(39):2398-2400, DOI: 10.14260/jemds/2016/557

\section{INTRODUCTION}

The optic nerve and internal carotid artery form two critical landmarks in the sphenoid sinus. These landmarks pose challenges during endoscopic sinus and skull based surgery. ${ }^{1}$ The optic nerve has been described in western literature to have four different configurations ranging from coursing adjacent to sphenoid sinus to traversing the sinus posing radically different challenges to the operating surgeon. ${ }^{2}$ The objective of this study is to determine the incidence of these optic nerve configurations in the Indian population.

\section{MATERIALS AND METHODS}

Computed tomography scans of Paranasal sinuses in 101 patients presenting with chronic rhinosinusitis were reviewed; $3 \mathrm{~mm}$ axial and coronal reformatted images were reviewed for optic nerve configuration, optic nerve dehiscence and anterior clinoidal pneumatisation. Patients less than 16 years of age, history of previous endonasal surgery, orbital surgeries, facial trauma and erosive pathologies were

Financial or Other, Competing Interest: None.

Submission 04-04-2016, Peer Review 28-04-2016,

Acceptance 03-05-2016, Published 16-05-2016.

Corresponding Author:

Dr. P. Thirunavukarasu,

\#77, Defence Officers Colony,

Ekkaduthangal,

Chennai-600032.

E-mail: druroboricforms@gmail.com

DOI: $10.14260 /$ jemds $/ 2016 / 557$ excluded from the study. Optic nerve configurations were categorized according to DeLano's classification. ${ }^{2}$ Optic nerve configurations were noted separately for right and left sides. Optic nerve dehiscence was defined as complete loss of bony density around the optic nerve. Presence of horizontal septations in the sphenoid sinus were indicative of an Onodi cell. ${ }^{3}$ In total, 202 optic nerves were studied.

\section{RESULTS}

A total number of scans reviewed were of 101 patients constituting 202 optic nerves; 64 males and 37 females were included in the study. The majority of patients fell in the 21-40 years' age group (61.38\%).

\begin{tabular}{|c|c|c|}
\hline Sex & No. of Patients & Percentage \\
\hline Male & 64 & 63.4 \\
\hline Female & 37 & 36.6 \\
\hline Total & $\mathbf{1 0 1}$ & $\mathbf{1 0 0}$ \\
\hline \multicolumn{3}{|c|}{ Table 1: Sex Profile } \\
\hline
\end{tabular}

\begin{tabular}{|c|c|c|}
\hline Age (Years) & No. of Patients & Percentage \\
\hline $16-20$ & 7 & 6.93 \\
\hline $21-40$ & 62 & 61.38 \\
\hline $41-60$ & 26 & 25.75 \\
\hline$>60$ & 6 & 5.94 \\
\hline Total & $\mathbf{1 0 1}$ & $\mathbf{1 0 0}$ \\
\hline \multicolumn{3}{|c|}{ Table 2: Age Groups } \\
\hline
\end{tabular}


112 Type I optic nerves were found constituting 55.45\% of all configurations; $75 \%$ of Type I configurations were bilateral. There was no significant difference in right sided Type I (14\%) versus left sided Type I (11\%).

\begin{tabular}{|c|c|c|}
\hline Involvement & No. of Patients & Percentage \\
\hline Bilateral & 48 & 75 \\
\hline Right & 9 & 14 \\
\hline Left & 7 & 11 \\
\hline Total & $\mathbf{6 4}$ & $\mathbf{1 0 0}$ \\
\hline \multicolumn{3}{|c|}{ Table 3: Type I Optic Nerves } \\
\hline
\end{tabular}

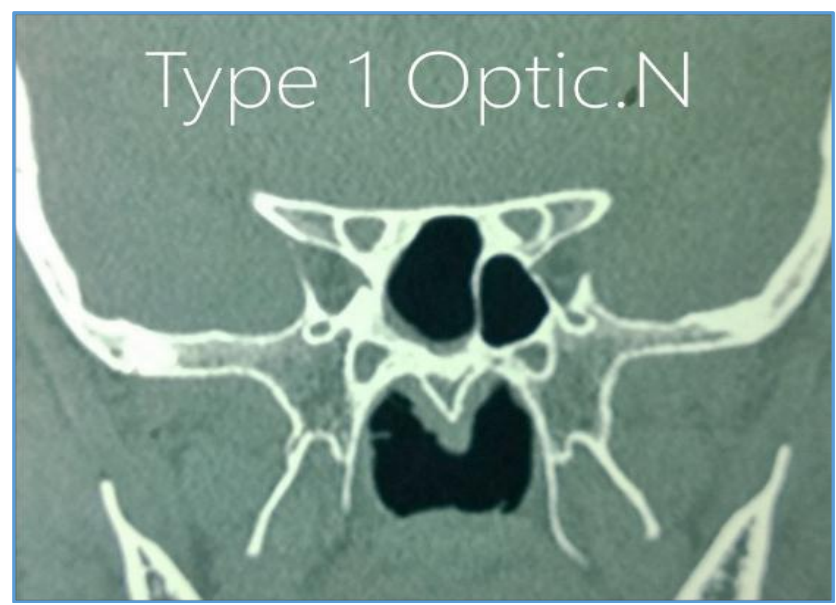

Fig. 1

Type II optic nerve configuration was found in $23.27 \%$, making it the second most common configuration. Bilateral Type II nerves were the most common (38.2\%). No significant difference existed between right side (35.3\%) versus left side (26.5\%).

\begin{tabular}{|c|c|c|}
\hline Involvement & No. of Patients & Percentage \\
\hline Bilateral & 13 & 38.2 \\
\hline Right & 12 & 35.3 \\
\hline Left & 9 & 26.5 \\
\hline Total & $\mathbf{3 4}$ & $\mathbf{1 0 0}$ \\
\hline \multicolumn{2}{|c|}{ Table 4: Type II Optic Nerve } \\
\hline
\end{tabular}

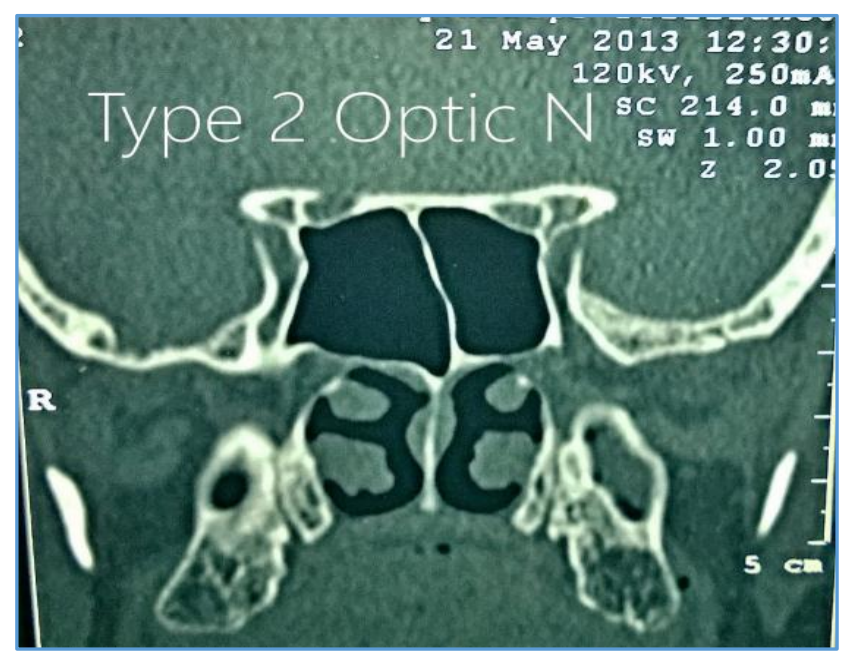

Fig. 2
Type III configurations were associated with pneumatized anterior clinoidal process and were the least common configuration (9.4\%). No dehiscent optic nerves were noted.

\begin{tabular}{|c|c|c|}
\hline Involvement & No. of Patients & Percentage \\
\hline Bilateral & 3 & 18.75 \\
\hline Right & 8 & 50 \\
\hline Left & 5 & 31.25 \\
\hline Total & $\mathbf{1 6}$ & $\mathbf{1 0 0}$ \\
\hline \multicolumn{3}{|c|}{ Table 5: Type III Optic Nerve } \\
\hline
\end{tabular}

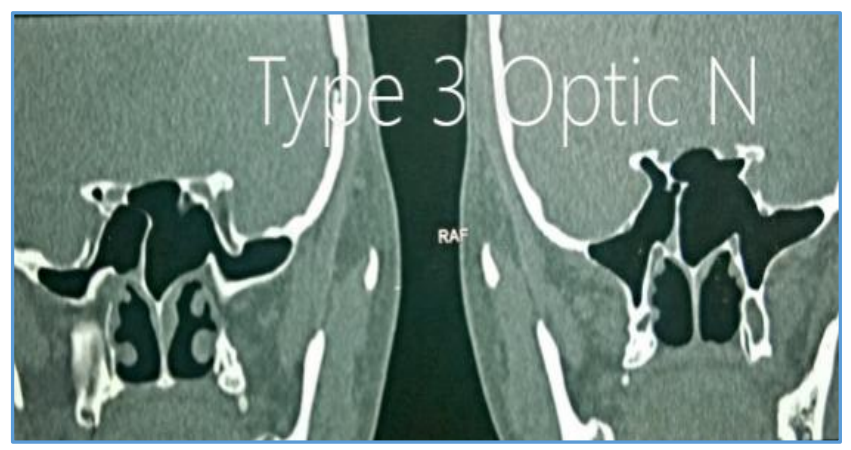

Fig. 3

Type IV nerves were associated with an Onodi cell and traversed both the posterior ethmoids and the sphenoid sinus. Type IV nerves were found in $11.88 \%$. Significantly most Type IV nerves were found to be on the left side (61.9\%) as opposed to the right $(23.8 \%)$.

\begin{tabular}{|c|c|c|}
\hline Involvement & No. of Patients & Percentage \\
\hline Bilateral & 3 & 14.3 \\
\hline Right & 5 & 23.8 \\
\hline Left & 13 & 61.9 \\
\hline Total & $\mathbf{2 1}$ & $\mathbf{1 0 0}$ \\
\hline \multicolumn{2}{|c|}{ Table 6: Type IV Optic Nerve } \\
\hline
\end{tabular}

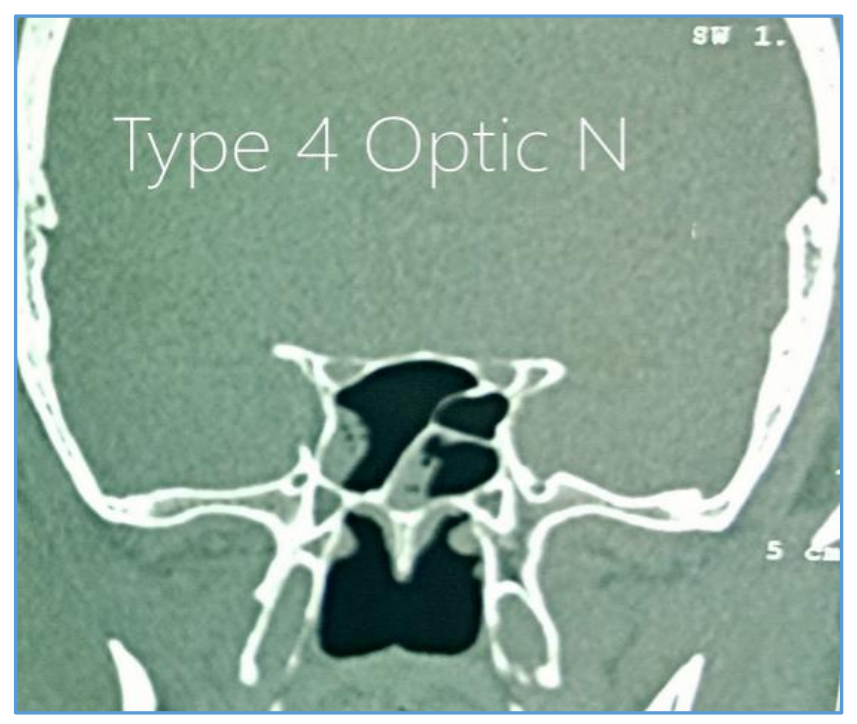

Fig. 4 


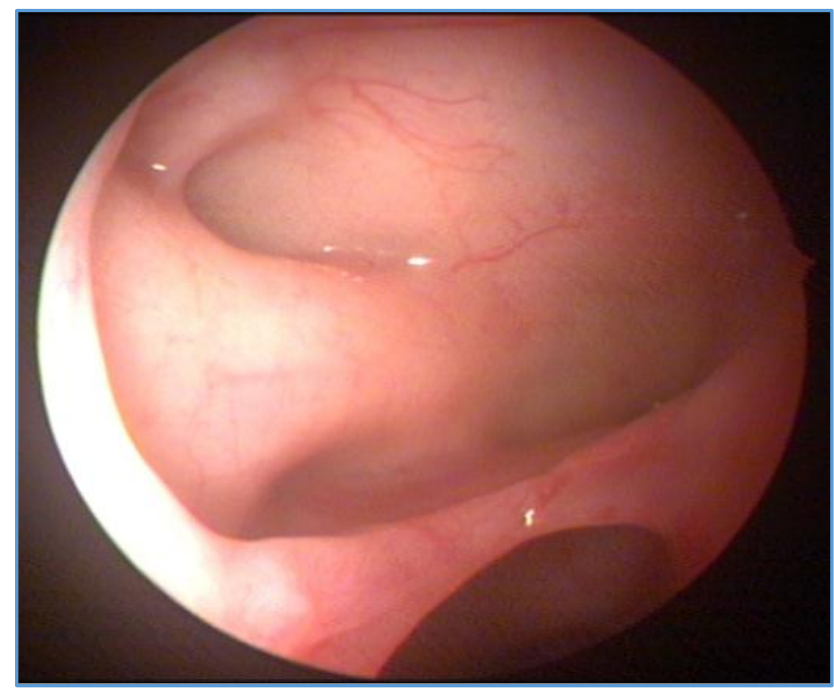

Fig. 5: Optic Nerve Traversing an Onodi Cell

\begin{tabular}{|c|c|c|}
\hline & No. of Nerves & Percentage \\
\hline I & 112 & 55.45 \\
\hline II & 47 & 23.27 \\
\hline III & 19 & 9.40 \\
\hline IV & 24 & 11.88 \\
\hline Total & $\mathbf{2 0 2}$ & $\mathbf{1 0 0}$ \\
\hline \multicolumn{2}{|c|}{ Table 7 } \\
\hline
\end{tabular}

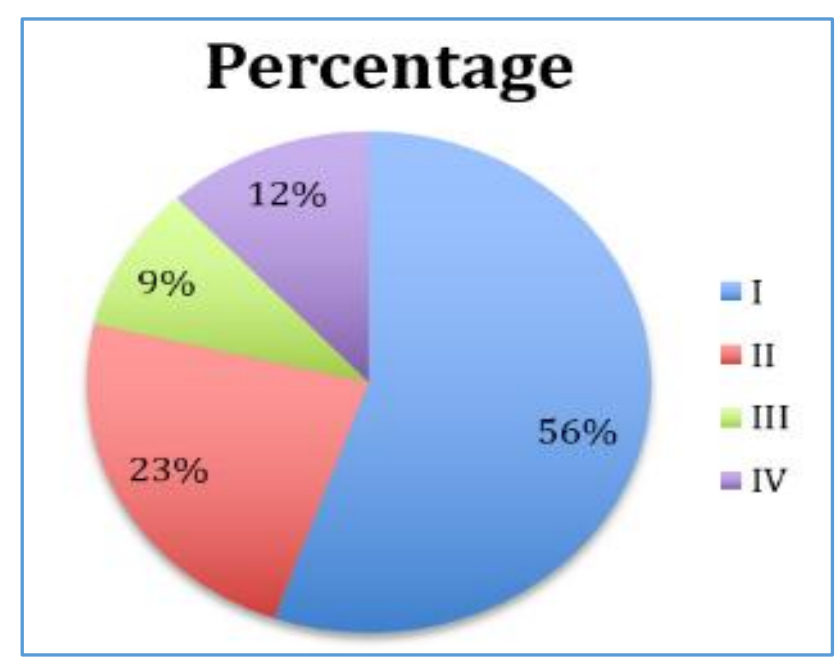

Chart 1: Percentage of Nerves Involved

\section{DISCUSSION}

Since the advent of era of Endoscopic Sinus Surgery, the Onodi or Sphenoethmoidal cell has received renewed interest. The Onodi cell was first described in the early $20^{\text {th }}$ century by Adolf Onodi. ${ }^{3}$ The renewed interest coincided with the recognition that an Onodi cell if unrecognized pre-operatively could lead to iatrogenic optic nerve injury. ${ }^{1}$
DeLano, in his landmark study classified optic nerve configurations into 4 types with type I the most common (76\%) and type IV the least (3\%). DeLano noted 100\% dehiscence in type III configurations, while we found none. ${ }^{3}$

Driben et al showed a 7\% incidence of Onodi cells in their study of 41 computed tomography scans. 4

Ji-Hyeon Shin et al observed a 32.7\% incidence of Onodi cells in pre-operative scans of 162 patients undergoing surgery. 5

Thanaviratananich et al showed a very high incidence $(60 \%)$ of Onodi cells in the oriental population. The study was conducted on Thai cadavers as opposed to computed tomography in other studies. ${ }^{6}$

An Indian population study in 50 patients by K. Dua et al showed a $6 \%$ incidence of Onodi cells. ${ }^{7}$

\section{CONCLUSION}

This study correlates with the overall incidence of optic nerve configuration published in western literature. Significantly, we found no optic nerve dehiscence in our study. This difference could be due to our definition of optic nerve dehiscence as complete bony cover absence as opposed to bony thinning of the canal. Onodi cells were found in $11.88 \%$ of the scans and were significantly left sided (61.9\%). It is our contention that a careful review of computed tomography scan should be undertaken by the endoscopic sinus surgeon to avoid catastrophic optic nerve injuries. It is also our opinion a simple bony thinning of the optic nerve canal would not constitute a surgically significant dehiscence.

\section{REFERENCES}

1. Maniglia AJ. Fatal and major complications secondary to nasal and sinus surgery. Laryngoscope 1988;99(3):27683.

2. Delano MC, Fun FY, Zinreich SJ. Relationship of the optic nerve to the posterior paranasal sinuses: a CT anatomy study. AJNR Am J Neuroradiol 1996;17(4):669-75.

3. Onodi A. The optic nerve and the accessory cavities of the nose. Ann Otol Rhinol Laryngol 1908;17:1-61.

4. Driben JS, Bolger WE, Robles HA, et al. The reliability of computerized tomographic detection of the onodi (sphenoethmoid) cell. Am J Rhinol 1998;12(2):105-11.

5. Ji-Hyeon Shin, Kim SW, Hong YK, et al. The onodi cell: an obstacle to sellar lesions with a transsphenoidal approach. Otolaryngology-head and neck surgery 2011;145(6):1040-2.

6. Thanaviratananich S, Chaisiwamongkol K, Kraitrakul S, et al. The prevalence of an onodi cell in adult thai cadavers. Ear Nose Throat J 2003;82(3):200-4.

7. Dua $K$, Chopra $H$, Khurana AS, et al. CT scan variations in chronic sinusitis. Indian J Radiol Imaging 2005;15:315-20. 